\title{
Deleterious BRIP1 Gene Mutation
}

National Cancer Institute

\section{Source}

National Cancer Institute. Deleterious BRIP1 Gene Mutation. NCI Thesaurus. Code C131774.

A change in the nucleotide sequence of the BRIP1 gene that is associated with increased risk of disease. 